\title{
Export Comparative Advantage Analysis of Iranian Hen Egg by RCA \& RSCA and RC Criteria
}

\author{
Farhad Mirzaei $^{{ }^{*}}$, Syed Mostafa Mostafavi ${ }^{2}$, Saeed Yazdani ${ }^{3}$ \\ ${ }^{1}$ Department of Animal Production and Management, Animal Sciences Research Institute of Iran, Karaj, Iran \\ ${ }^{2}$ Iran Branch, World's Poultry Science Association, Tehran, Iran \\ ${ }^{3}$ Department of Agricultural Economics, Faculty of Agriculture, University of Tehran, Karaj, Iran \\ Email: *farmir2003203@yahoo.com
}

Received May 8, 2012; revised June 10, 2012; accepted June 18, 2012

\begin{abstract}
The potential impact of a liberalization of global trade on developing nations is a controversial subject. The liberalization of global agricultural trade, in particular, has been the focus of the debate for many years now and is part of the current WTO negotiations. Trade policies are believed to have influenced a country's comparative advantage. Comparative advantage as a concept for evaluating the patterns of trade, is widely accepted and often used in theoretical and policy discussions. Livestock and livestock products, in the global trade, account for about one sixth, by value, of all agricultural trade. Iran is the one of main producers of hen egg in the world (FAO, 2004). Higher-than-global cost prices are the main disadvantage of the Iranian hen egg industry. The industry comprises of 700 million broiler day-old chicks, 10 million broiler breeders and 50 million layer day-old chicks. Hen egg is one of the Livestock products which are part of the non-oil export in Iran and its export consistently faces with fluctuation during last years. This paper looks at the performance of hen egg export and examines the comparative advantages indices like: revealed comparative advantage (RCA), revealed symmetric comparative advantage (RSCA) and (revealed competitive advantage (RC) for Iran and world main producers over the period 1990-2005. The source of data from 1990-2005 are supplied by FAO (2006). The changes in Iran's export structure were compared with main producers ones. The results of the research showed, the trade and production policies and economic behavior of producers and exporters have been in such a way that they could not show a appropriate and timely response of world, also the revealed instabilities in the trends of RCA, RSCA and RC indices during the study period led to the conclusion that there is no well defined strategy and plan for utilization of low price production factors, effectiveness human power, knowledge of bargaining power and target markets. The objective of this paper is to try to identify: 1 ) The export comparative advantage of Iranian hen egg; 2) Its changing during the time; 3 ) The comparative advantage of Iranian hen egg in competition with other countries which are famous in trade and production of hen egg.
\end{abstract}

Keywords: Revealed Comparative Advantage; Hen Egg; Export; Trade; Iran

\section{Introduction}

Even agriculture in $21^{\text {st }}$ century has been currently at the forefront of the debate over the globalization, it is more competitive than in the past. The agreement under the auspices of World Trade Organization (WTO) would allow all nations to focus on the benefits from realizing comparative and competitive advantage in the international economy and increasing competition would force resources to be allocated more efficiently. The potential impact of liberalization of global trade on developing nations is a controversial subject. The liberalization of global agricultural trade, in particular, has been the focus of the debate for many years now and is part of the current WTO negotiations. Trade policies are believed to have influenced

\footnotetext{
"Corresponding author.
}

a country's comparative advantage, so as a concept for evaluating the patterns of trade, is widely accepted and often used in theoretical and policy discussions. Livestock and livestock products, in the global trade, account for about one sixth, by value, of all agricultural trade. There is 5500 millions laying hen in the world and 56 millions in Iran ( $7^{\text {th }}$ in the world). Also, Iran is $1^{\text {st }}$ Hen egg producer in the Middle East, 6th in the Asia and $16^{\text {th }}$ in the world, so Iran is the one of main producers of Hen egg in the world [1]. Higher global cost prices are the main disadvantage of the Iranian egg industry. The industry comprises of 700 million broiler day-old chicks, 10 million broiler breeders and 50 million layer day-old chicks. Hen egg is one of the Livestock products which are part of the non-oil export in Iran and its export consistently faces with fluctuation during last years [2]. The objective of 
this paper is to try to identify: 1) The export comparative advantage of Iranian hen egg; 2) Its changing during the time; 3) The comparative advantage of Iranian hen egg in competition with other countries which are famous in trade and production of hen egg.

\section{Material and Methods}

This paper looks at the performance of hen egg export and examines the comparative advantages indices like: RCA, RSCA and RC for Iran and world main producers over the period 1990-2005. The source of data from 19902005 are supplied by FAO in 2006. We used from RCA method as follows:

\section{1. $\mathrm{RCA}=(\mathrm{Xij} / \mathrm{Xtj}) /(\mathrm{Xin} / \mathrm{Xtn})$}

The concept of revealed comparative advantage (RCA) is grounded on conventional trade theory. The original RCA index is formulated by Balassa [3], can be written as: Where $\mathrm{X}$ represents exports value (1000\$), $\mathrm{i}$ is a country (Iran), $\mathrm{j}$ is a commodity (hen eggs), $\mathrm{t}$ is a set of commodities (agricultural products) and $\mathrm{n}$ is a set of countries (world), RCA is based on observed trade patterns, it measures a country's export of a commodity in relation to its total exports and to the corresponding export performance of a set of countries. If RCA $>1$, then a comparative advantage is revealed. Many researchers have attempted to refine revealed comparative advantage [4-7]. A problem with the Balassa index is that its value is asymmetric; it varies from one to infinity for products in which a country has a revealed comparative advantage, but only from zero to one for commodities with a comparative disadvantage. Dalum et al. [8] proposed a revealed symmetric comparative advantage (RSCA) index to alleviate the skewness problem as follows:

\section{2. $\quad \operatorname{RSCA}=(\operatorname{RCA}-1) /(\operatorname{RCA}+1)$}

The RSCA ranges is from minus one to plus one and avoids the problem of zero values. we focused on hen eggs and agricultural sectors and investigate the stability in the pattern of the RCA indices for Iran. Also, using market share as a measure of competitiveness, indicators of competitiveness can be developed. These indicators are ex post measures based on past performances. Vollrath [7] developed a comprehensive index called revealed competitive advantage (RC). This index includes imports (M) as well as exports (X). Avoids the problem of double counting and permits intra-industry trade. The revealed competetive advantage index is written as:

$$
\text { 2.3. } \begin{aligned}
\mathrm{RC}= & {[(\mathrm{Xij} / \mathrm{Xtj}) /(\mathrm{Xin} / \mathrm{Xtn})] } \\
& -[(\mathrm{Mij} / \mathrm{Mtj}) /(\mathrm{Min} / \mathrm{Mtn})]
\end{aligned}
$$

The revealed competitive advantage index as a measure of competitiveness shows how well a country's particular economic sector competes abroad and at home. A positive RC measure demonstrates that country i has a competitive edge in producing and trading commodity $\mathrm{j}$.

\section{Results and Discussion}

The distribution of the RCA indices in the start and end years of the period is indicated non uniformity, so RSCA and RC indices confirm the results gained from RCA indices (Table 1, Figure 1). Also this research has been shown the trend of share of Iran's production from world production, share of Iran's export from Iran's production and share of Iran's export from world export in terms of weight and value (Table 2, Figure 2). The contribution of Iran's hen egg production in relation to world had increasing process, so that according to FAO, Iran has gained the first grade in the Middle East, $7^{\text {th }}$ in Asia and $17^{\text {th }}$ in the world but contribution of Iran's export from total hen egg export in the world market don't have increasing process. It seems. Instability and in coordination of production policies and elasticity of market is the reason of fluctuating of contribution of Iran's production in the region over the studied period. Furthermore, the contribution value of Iran's hen egg export from total value of hen egg export in the world is less than the contribution of Iran's export weight from total weight in the world. With this comparison, we find out that in relation to average price of each kilograms of the product in region, Iran gains less price for each kilograms of its export. This matter is possibly for the reason of either low quality of Iran's hen egg from average quality of hen egg of regional producers or impossibility of timely availability to region markets particularly lack of bargaining power, which it is in agreement with Salami et al. findings [9] According to results, we can conclude that with regard to allocation of first grade of production of mentioned product to Iran, the RCA indices in the world has fluctuating rate to the comparative advantage that in case of coordination of decision-making centers of production and trade and awareness from existing atmosphere in region, obtaining the continuous comparative advantage export for Iran's hen egg production will be available. For these reasons, we can't recommend that Iran regarding to fluctuable RCA indices, having changeable RSCA and nonsubstantiativeness RC, must retreat from recent decade of production policies for hen egg production.

\section{Conclusion}

The distribution of the RCA indices indicated non uniformity and was confirmed with the indices of RSCA and RC. The contribution of hen egg production has been increasing but the country's total hen egg production in the world is not stable due to problems in coordination of 
Table 1. RCA, RSCA and RC indices of Iran's hen eggs export in the world.

\begin{tabular}{cccc}
\hline Year & RCA & RSCA & RC \\
\hline 1990 & 0.01459 & -0.97124 & 0.007 \\
1991 & 0.02547 & -0.95032 & -0.17 \\
1992 & 0 & -1 & -0.78 \\
1993 & 0 & -1 & -0.86 \\
1994 & 2.17280 & 0.36964 & 2.009 \\
1995 & 0.01109 & -0.97806 & -3.82 \\
1996 & 0 & -1 & -10.72 \\
1997 & 0.10475 & -0.81036 & -1.27 \\
1998 & 0.20420 & -0.66085 & 0.552 \\
1999 & 0.33232 & -0.50114 & 0.199 \\
2000 & 4.01307 & 0.60104 & 5.26 \\
2001 & 2.70096 & 0.45960 & 4.71 \\
2002 & 2.49711 & 0.42810 & 1.65 \\
2003 & 2.84321 & 0.47916 & 4.82 \\
2004 & 2.2449 & 0.38364 & 2.02 \\
2005 & 2.3569 & 0.40421 & 4.22 \\
\hline
\end{tabular}

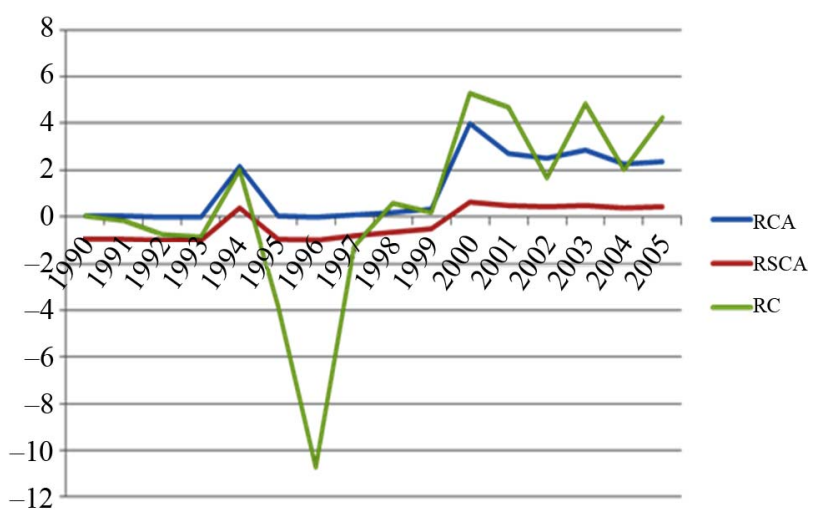

Figure 1. RCA, RSCA and RC indices of Iran's hen eggs export in the world.

production policies and elasticity of the region's market, so Iran was $14^{\text {th }}$ exporter in 2002, $13^{\text {th }}$ player in 2001 and $10^{\text {th }}$ main partner in 2000 with respect to hen egg market in the world. Besides, the value of Iran's hen egg export out of the total value of hen egg export of the region is less than the Iranian export weight. It was observed that Iran gains lower price per a kilogram export. This may be attributed to low quality hen egg and low standardization process from average quality and standardization factors of hen egg of other competitors or poor bargaining power. Trade and production policies and economic behavior of producers and exporters have been in such a way that they could not show a appropriate and timely response of
Table 2. Trend of Iran's production share (IPS) from world production (WP), Iran's export share (IES) from Iran's production (IP), Iran's export weight share (IEWS) from world export (WE) and Iran's export value share (IEVS) from world export (WE).

\begin{tabular}{ccccc}
\hline Year & IPS/WP & IES/IP & IEVS/WE & IEWS/WE \\
\hline 1990 & 0.233 & 0.0000169 & 0.001 & 0.000204 \\
1991 & 0.257 & 0.0000294 & 0.002 & 0.000383 \\
1992 & 0.271 & 0 & 0 & 0 \\
1993 & 0.281 & 0 & 0 & 0 \\
1994 & 0.306 & 0.28246 & 0.276 & 0.264 \\
1995 & 0.281 & 0.0000323 & 0.001 & 0.000559 \\
1996 & 0.326 & 0 & 0 & 0 \\
1997 & 0.276 & 0.001402 & 0.009 & 0.011 \\
1998 & 0.267 & 0.00398 & 0.022 & 0.033 \\
1999 & 0.301 & 0.00396 & 0.039 & 0.062 \\
2000 & 0.301 & 0.06662 & 0.481 & 0.647 \\
2001 & 0.318 & 0.05663 & 0.311 & 0.507 \\
2002 & 0.297 & 0.03163 & 0.281 & 0.473 \\
2003 & 0.321 & 0.08762 & 0.493 & 0.658 \\
2004 & 0.301 & 0.05363 & 0.303 & 0.498 \\
2005 & 0.296 & 0.02986 & 0.272 & 0.457 \\
\hline
\end{tabular}

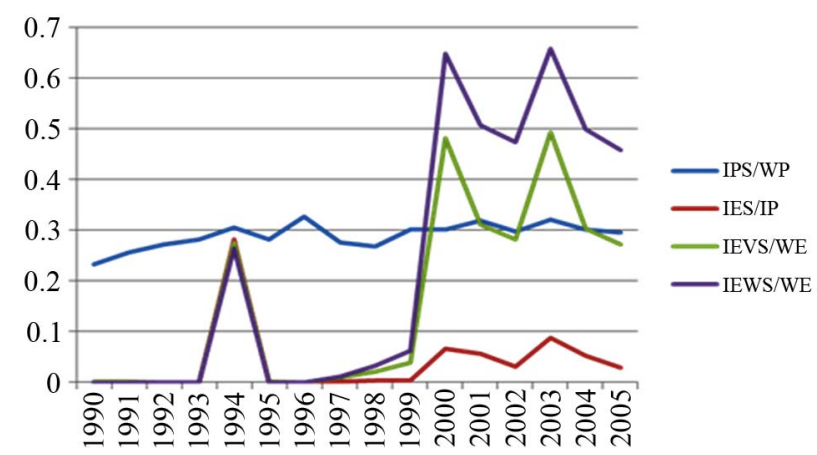

Figure 2. Trend of Iran's production share (IPS) from world production (WP), Iran's export share (IES) from Iran's production (IP), Iran's export weight share (IEWS) from world export (WE) and Iran's export value share (IEVS) from world export (WE).

region, also the revealed instabilities in the trends of RCA, RSCA and RC indices during the study period (1990-2005) led to the conclusion that there is no well defined strategy and plan for utilization of low price production factors, effective human power, knowledge of bargaining power and target markets. Also regarding to poultry industry potential, we can't recommend that Iran because of fluctuable RCA, RSCA, RC indices, must retreat from recent decade of production policies for hen egg production.

\section{Acknowledgements}

With thanks from Animal Science Research Institute 
because of their financial support to achievement of this research.

\section{REFERENCES}

[1] Food and Agriculture Organization, "Trade Yearbook,” 2006. www.fao.org

[2] F. Mirzaei, S. Yazdani and A. A. Gharahdaghi, "Survey on Comparative Advantage of Chicken Meat Export of Iran in the World," The 2nd Iranian Poultry Science Seminar, Animal Science Research Institute, Karaj, 29-30 January 2003, pp. 150-155.

[3] B. Balassa, "Trade Liberalization and Revealed Comparative Advantage," The Manchester School of Economic and Social Studies, Vol. 33, No. 2, 1965, pp. 99123.

[4] J. B. Donges and J. Riedel, “The Expansion of Manufactured Exports in Developing Countries: An Empirical Assessment of Supply and Demand Issues," Review of World Economics, Vol. 113, No. 1, 1977, pp. 58-87. doi:10.1007/BF02696566
[5] K. Kunimoto, “Typology of Trade Intensity Indices,” Hitotsubashi Journal of Economics, Vol. 17, No. 2, 1977, pp. 15-32.

[6] H. P. Bowen, "On the Theoretical Interpretation of Trade Intensity and Revealed Comparative Advantage," Review of World Economics, Vol. 119, No. 3, 1983, pp. 464-472. doi:10.1007/BF02706520

[7] T. L. Vollrath, "A Theoretical Evaluation of Alternative Trade Intensity Measures of Revealed Comparative Advantage," Review of World Economics, Vol. 127, No. 2, 1991, pp. 265-280. doi:10.1007/BF02707986

[8] B. Dalum, K. Laursen and G. Villumsen, "Structural Change in OECD Export Specialization Patterns: De-Specialisation and Stickiness,', International Review Applied Economics, Vol. 12, No. 3, 1998, pp. 447-467.

[9] H. Salami and E. Pishbahar, "Changes in the Patterns of Comparative Advantage of Agricultural Products in Iran; An Empirical Analysis Based on the Revealed Comparative Advantage Indices,” Agricultural Economics and Development Scientific \& Research Quarterly Journal, Vol. 34, No. 9, 2001, pp. 67-99. 